\title{
Sir Colin St. John ('Sandy') Wilson:
}

\section{2-2007}

One of Britain's great architectural thinkers, the architect of the British Library, Professor Sir Colin St. John Wilson died on 14 May 2007 at the age of 85. Wilson, known as 'Sandy' to his friends, had been a significant figure since his days at the LCC in the 1950 s, having become a tireless champion of reasoned argument. He was a deeply erudite man of letters - a passionate and expert collector of contemporary British art which led to his being asked to serve as a Trustee of both the Tate and the National Galleries. He was also a Royal Academician. Wilson's architectural motivation was, above all, to champion the potential of architecture to address human life at the deepest level both in theory and, most importantly for him, in practice. Wilson leaves behind an oeuvre of seminal texts on the making and experiencing of architecture, a portfolio of innovative buildings, including his magnum opus - the immense British Library (1998), and a unique collection of British art donated to the nation, now housed at the prize-winning Pallant House Extension (2006) that he designed with Long and Kentish.

Born in Cheltenham, in 1922, Wilson grew up in a Church family. When his father was made Bishop of Chelmsford, the family moved into the limelight where Wilson witnessed his father (known, in some quarters, as the 'Red Bishop') speaking up for his beliefs, often against hostility from both the establishment and the press. Wilson inherited his father's striking physical presence. When he stood his ground and spoke his mind, he did so with impressive authority. Behind his impassioned theoretical pronouncements there were long periods of laboured contemplation as well as an immense strength of belief. During

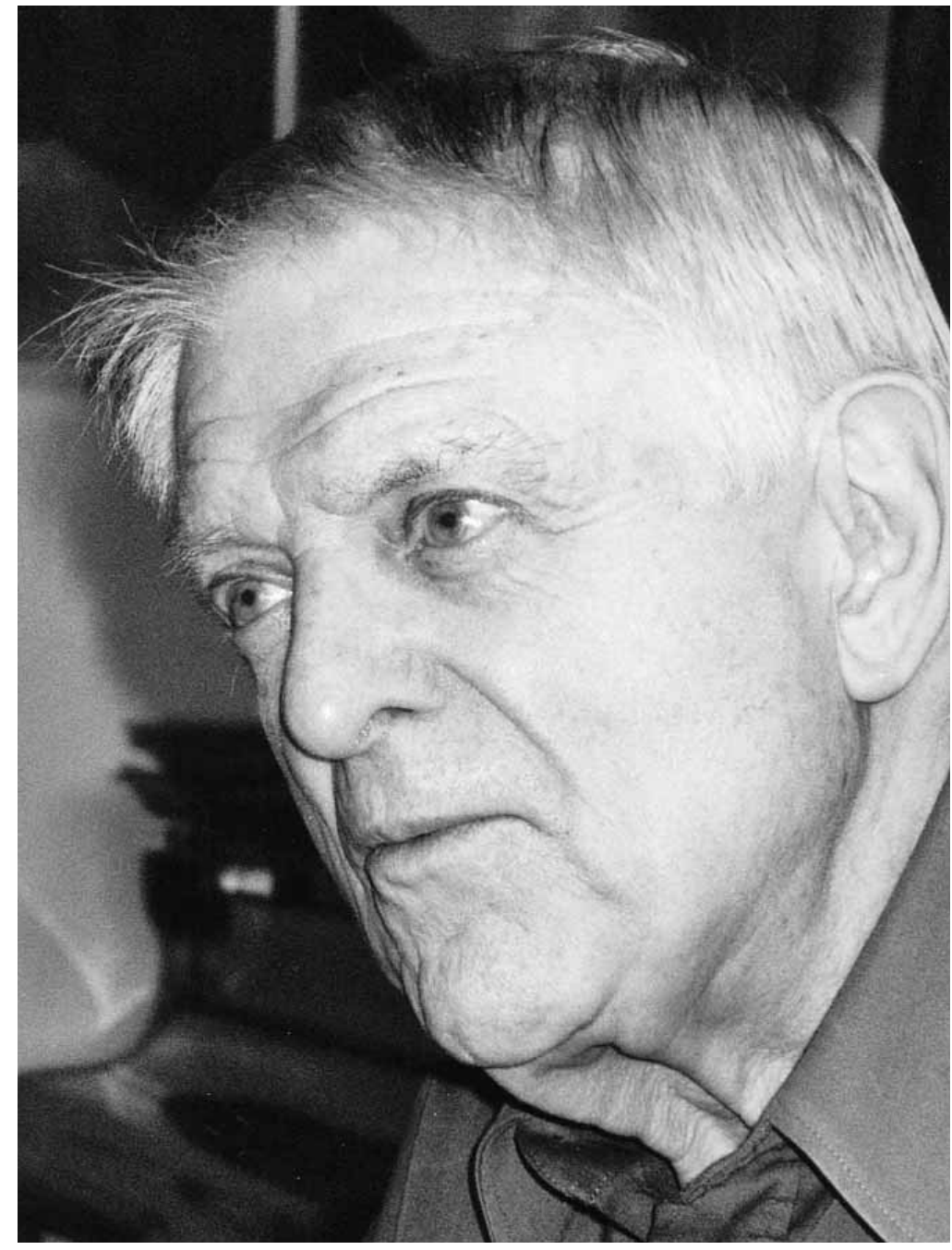

1 Sandy Wilson, St. John's Wood, May 2005

the period when his practice was besieged by hostility when the British Library construction and its schedule (which was largely controlled by Government blunders) were erroneously reported, or when prejudiced and unqualified Royal denouncements of the Library were being uttered, Wilson remained firm in the belief articulated by his mentor, Aalto: 'The truth is in buildings not talk'. On this issue Wilson triumphs in every moment of pleasure the Library brings to its millions of users and visitors. The fact that he did not become embittered is a testament to his self-belief, and a deep ineffable Christian faith that motivated him in a tireless search 
for the richest way to fully accommodate the 'little man' - as Aalto put it - 'his tragedy and comedy - both'. ${ }^{2}$ Such theological and ethical influences had commingled from his earliest youth with passions for art and literature. When Wilson first went up to Cambridge to take a war degree in 1940 to study history, he spent more time painting than studying, and was quickly bored by history. He then transferred to the architecture course because, he recalled, 'there was an element of drawing in it'. At this stage art remained the most important thing 'to the exclusion', he said 'of everything else'. ${ }^{3}$

\section{Art and life}

After an uneventful war in the Navy, stationed in India, Wilson returned to complete his architectural training at what he found to be an 'earnest but rather architecturally stodgy' Bartlett, where there was no interest in Modernism. Aided by Adrian Stokes' art analysis, he then began to take Italian sojourns during which architecture grew on him through the commingling of lavish colour and form in the Veneto. This stimulated a realisation that at the heart of aesthetic delight was something psycho-physical. Only as these experiences of art and architecture came together with exposure to the stimulating birth of Brutalism in the coffee 'salon' of Peter (Reyner) and Mary Banham - key protagonists in the 1950s art scene who just happened to live in the neighbouring flat in Primrose Hill to the one that Wilson took on qualifying in 1950 - did architecture become prima inter pares with art and literature. Thereafter, the passions of art, literature and philosophy remained vital to him, but were also requisitioned as essential tools for his exploration of the deepest nature of the nature and experience of architecture. Through the Banhams, Wilson met his first wife, Muriel Lavender - a young art historian, whom he married in 1955 (the marriage was later dissolved). His childhood passion for collecting was now channelled into the careful collecting of contemporary British art, and led to firm friendships with the likes of Paolozzi, Kitaj and Blake. He was an assiduous collector, acquiring not only final pieces, but the preliminary work that led to them. Much later he wrote insightfully about the process of making painting in The Artist at Work (1999). He was closely involved both with the

Independent Group of artists, and those who established the Institute of Contemporary Arts (ICA) in the 1950 .

Through his association with the Banhams, questions of society and politics (with a small 'p') began to have an impact on Wilson's sharp intellectual and strong aesthetic judgement. From this rich

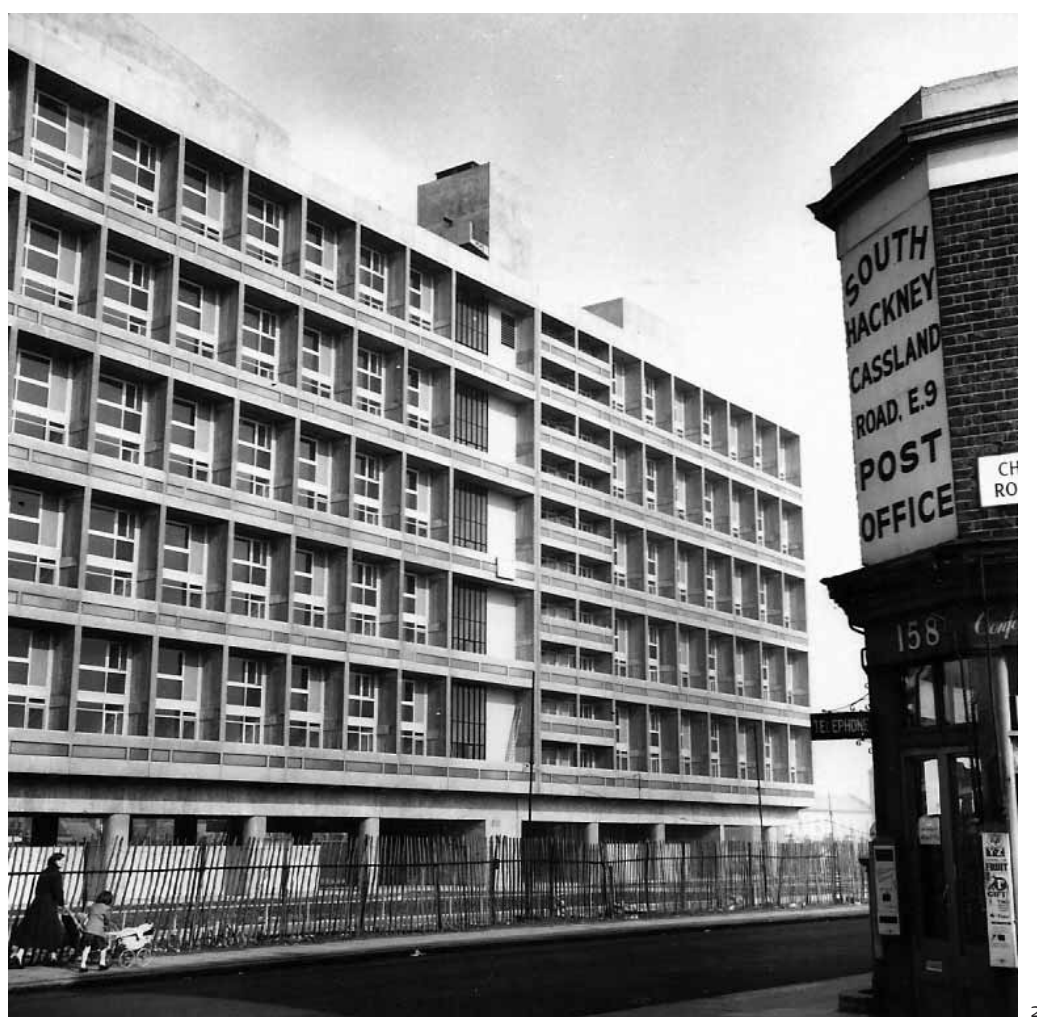

2 Newly completed Bentham Road estate (1955) in its 1950s Hackney context

admixture of an interest in social change, aesthetic delight, philosophical questioning and psychological intrigue there grew something of an ethical imperative wherein his moral and artistic drives united - eventually being articulated in his important essay, 'The Ethics of Architecture'. ${ }^{4}$

In 1950 Wilson began writing for The Observer through which he came to the attention of Leslie Martin at the London County Council (LCC). A little later Wilson heard that 'Everyone is going to the LCC', so he too applied to join the activities of a radical group of newly qualified architects working under Martin in the basement of County Hall to build the 'Brave New World'. Despite being out of college only a year, he soon found himself taking on huge housing projects, such as the homage to Corbu in the narrow-fronted maisonette 'Unité' prototype at Bentham Road [2]. Thus, by the mid 1950 s his passion for architecture had blossomed into a vivid determination; 'We were young and didn't have families, and certainly we were doctrinaire in the way that young architects can sure as hell be'. He was hunting - and searched out artists such as Giacometti and Brancusi in their lairs, and architects, such as Le Corbusier succeeding in not only meeting Corbu himself, but in being invited to his sanctum sanctorum - his home and studio in rue Nungesser-et-Coli, under the false pretence that he was to write the catalogue for an upcoming ICA exhibition of Corbu's paintings - which, de facto, he hastily arranged.

During this period Wilson also collaborated on competition designs with Arthur Baker and Peter Carter. Among other schemes, they presented a 'Vertical City' project at CIAM X in Dubrovnik, entered the Coventry Cathedral competition with a Miesian essay in metaphysics, ${ }^{5}$ and participated in the 'This is Tomorrow' exhibition in 1955 with an amorphous piece 'of sculptural architecture' close in spirit to the newly opened Ronchamp. ${ }^{6}$

\section{Translation to Cambridge}

In 1956 Leslie Martin was made Professor of Architecture at Cambridge, and called on the dynamic energy of his young colleague to assist him in Cambridge - both as a teacher and as a designer. Together Martin and Wilson oversaw what would be the transformation of a parochial architectural scene into a leading international centre of 
architectural research, teaching and creativity, drawing to it the persons and ideas of protagonists such as the Le Corbusier, Aalto, Saarinen, Kahn, Neutra, academics such as Rowe, Stokes, NorbergSchulz, and artists such as Moore and Rothko.

Wilson had a key role in the development of a number of Martin's projects, and in the development of important areas of research. For example, through their early King's College hostel accommodation project (1956), they began to re-examine the potential of the court typology and patterns of community. Rather than simply examining issues of density, they explored ideas of quality, urbanity, neighbourliness, the relation of inside and outside, and privacy, as well as practical matters such as day-lighting. For Wilson, these explorations generated something of an obsession for hanging gardens and stepped sections. The ideas also came to fruition in the immensely influential Harvey Court residential building for Gonville and Caius College, Cambridge (1957-62), in which Martin, Wilson and Patrick Hodgkinson collaborated. A seminal courtyard scheme of great formal power emerged, its bulky and uncompromising brick massing reminiscent of Aalto and Kahn, stepping down into its Arcadian setting, with its section offering a dual-aspect arrangement of varied rooms, and a 'hanging garden' of windows facing into the courtyard. Martin and Wilson soon took many of these ideas further in the Oxford Libraries (1959-64) where three libraries of different sizes and natures were brought together. The solution arose from an extremely close examination of the 'use' of each, under the umbrella theme of the courtyard. Here, as elsewhere, a determination to face the inherent problems and contradictions, to dwell on these, and allow their dialogue to generate a solution worked on the inside, while also creating rich external public form, was profound.

\section{Intimacy and architecture}

Within five years of visiting Corbu in his Parisian nest, Wilson's journey towards the new architecture was significantly disrupted by Aalto's denunciation of the Modernist 'dictatorship' during his 1957 Gold Medal Speech at the RIBA. The theoretical disturbance was profound as he instinctively answered the call to resist the narrowest of Modernist thought. This galvanised him to set

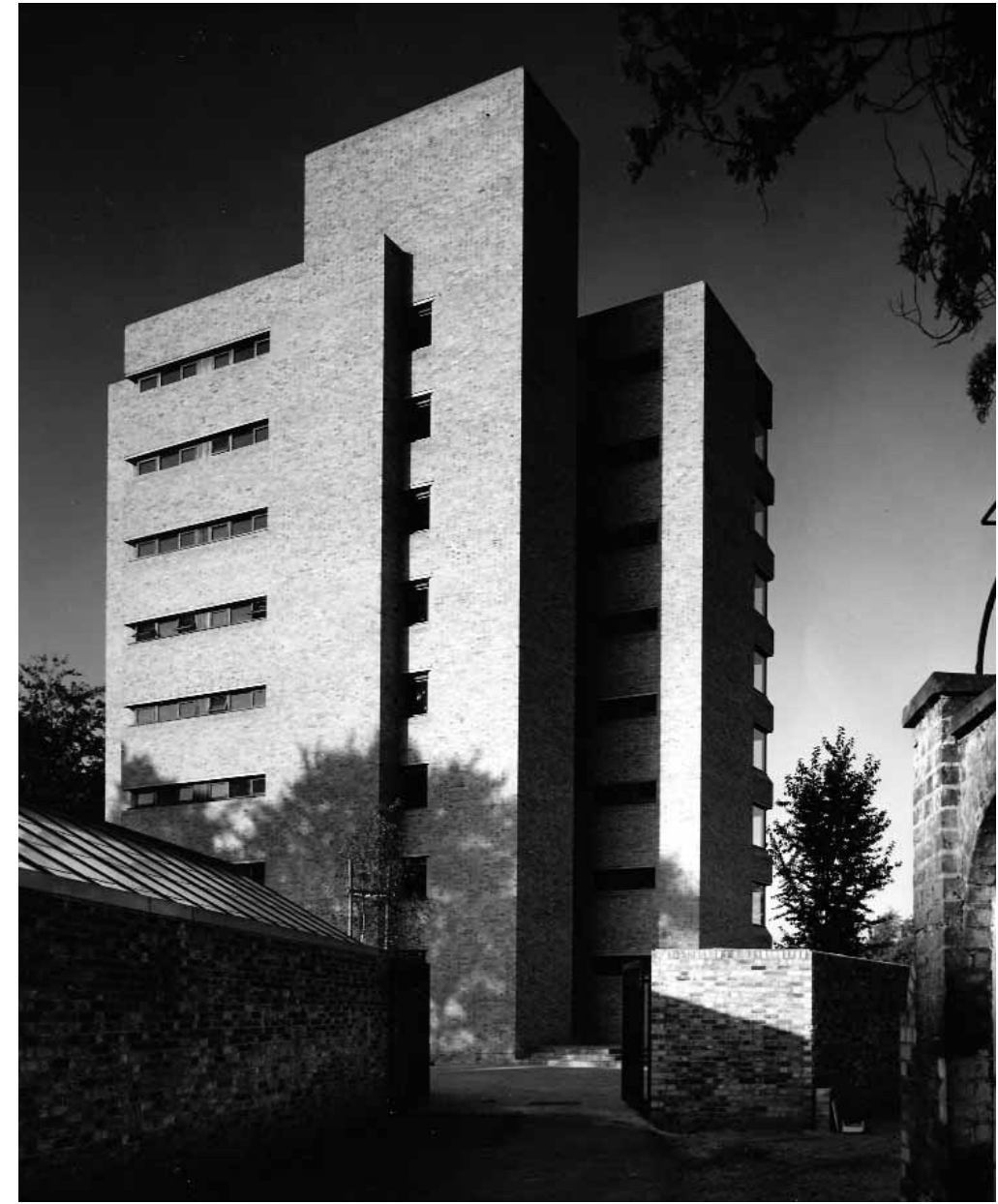

3 Martin and Wilson, Stone Building, Peterhouse, 1962

himself on a new track - towards Aalto's work in Finland - and, with typical confidence, he arrived (uninvited) at Aalto's eclectic 'masterpiece' Villa Mairea, where he was promptly invited to stay for the night, joining the Gullichsens and Aalto himself, who was there on a shooting trip. The reorientation of Wilson's architectural philosophy was under way.

As well as working with Martin, Wilson had begun his own practice in Cambridge. Among his early successes was the Extension to the School of Architecture Building, Cambridge (1957-58) designed with Alex Hardy. This building, run as a live project for students, exemplified the synergies of teaching and research. It was opened in 1958 by both Henry Moore and Le Corbusier. The cubic building of exposed brick and concrete embodies the aedicule theme, and borrows from Kahn the idea of served and serving spaces. Most striking of all it remains an essay in the incorporation of the metaphysical and corporeal realities - how a building can embody principle.

Wilson continued to contribute to Martin's large schemes, such as campus lay-outs for the new universities of Leicester and Hull. In 1960, Wilson was then given responsibility for a new dormitory for Peterhouse, The Stone Building (1960-62) [3]. Here, with 'quiet authority' ${ }^{7}$ he created a tall and richly textured brick building that carefully transplanted the urban high-rise idiom into a verdant garden setting. The plan is staggered, opening rooms up to the light and to offer views, not unlike Aalto's dormitory buildings.

Recognising the growing international reputation of the British architecture at the time, and in particular Harvey Court and Ham Common, Paul Rudolph, Professor at Yale, invited Wilson, his close friend Jim Stirling, and others including the Smithsons, to teach at Yale for a semester in 1960 and again in 1962. This introduced Wilson to the American architectural scene, and it to his theoretical stance - such as in a dialogue at a Symposium at Columbia University in 1964 when he challenged 'the prevailing indulgence in aesthetics or technology for their own sake', suggesting instead a need for 'probity' - which horrified Philip Johnson. 


\section{The 'in-between'}

Wilson brought these immense and valuable experiences into his own practice. In 1962 he began the design of two row houses in Cambridge: one house and studio for himself and his wife, and a smaller house for another Cambridge don. The Grantchester Road houses (1962-64) were a 'declaration of faith' of great intensity and rigid formalism, but also one in which he explored the themes of courtyard, the balance of public-private realm, and the process of 'passing into' and through the building [4]. This latter theme was to become a central tenet of his later theoretical work - as the 'inbetween'. However, the houses are also a result of a rigorous exploration of order, mass production and repetition, which created an exciting ambience, but one characterised by a certain naked rationality rather than domestic warmth.

In contrast, another private house and studio, the Cornford House, Cambridge (1965-67) extended a gentler, but no less exciting invitation [5]. Undertaken with a new assistant, M. J. Long, the architectural vocabulary is quite different, growing from the need to create a home which encouraged sociability, but also a place to make and display art. The harsh tone of the Grantchester Road concrete blocks was replaced with a warm brick and timber tectonic, and instead of the former's rigid rectilinearity the Cornford House is generated by a dynamic diagonal axis which draws the visitor into the heart of the house, and through, either to its hearth or out to the garden. The house reveals Wilson's influences at the time - among them Aalto's Säynätsalo, Moore's Sea Ranch, and Utzon's ideas of courtyard housing. But as well as citing its antecedents, the intimate and authentic Cornford House breaks new ground in its embodiment of Wilson's ideas about the latent content of architecture that stirs our memory with its hidden imagery, and his will to seek to accommodate the basic human need to 'be part of' and at the same time 'to be separate'. It is a work most intimately stimulated by the work of Adrian Stokes and his sources, which Wilson found was best accommodated in an ancient form - the aedicule. ${ }^{8}$ Much later, in his essay 'The Natural Imagination' (1989), Wilson was to articulate the ideas he thus embodied as 'envelopment' and 'exposure' - linking them to the theories of the Psychoanalytic thinker, Melanie Klein. ${ }^{9}$ Crucial was the fact that he knew these experiences of 'indefinable exhilaration', and sought to invite, even trigger awareness of such psycho-physical reality in his architecture, and examine and articulate it in accessible theory. This is one of his most unique contributions to architectural theory.

The other crucial theoretical contribution was Wilson's recognition and subsequent articulation of something

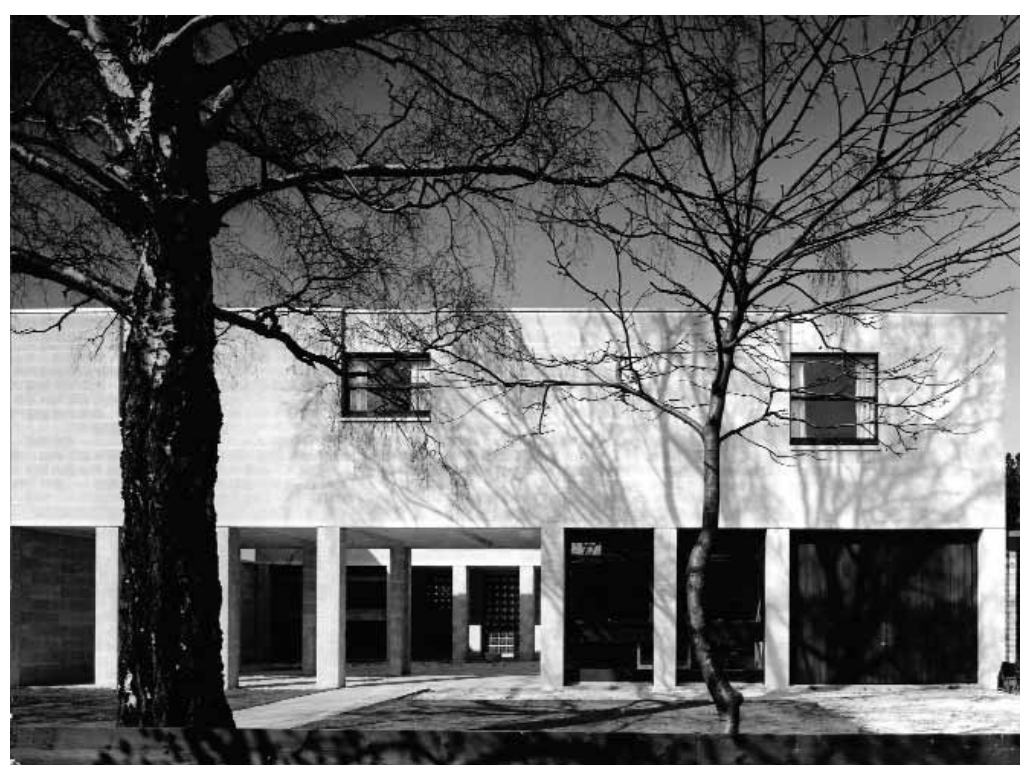

4 Entrance facade of 2a Grantchester Road, 1964. Photo Henk Snoek

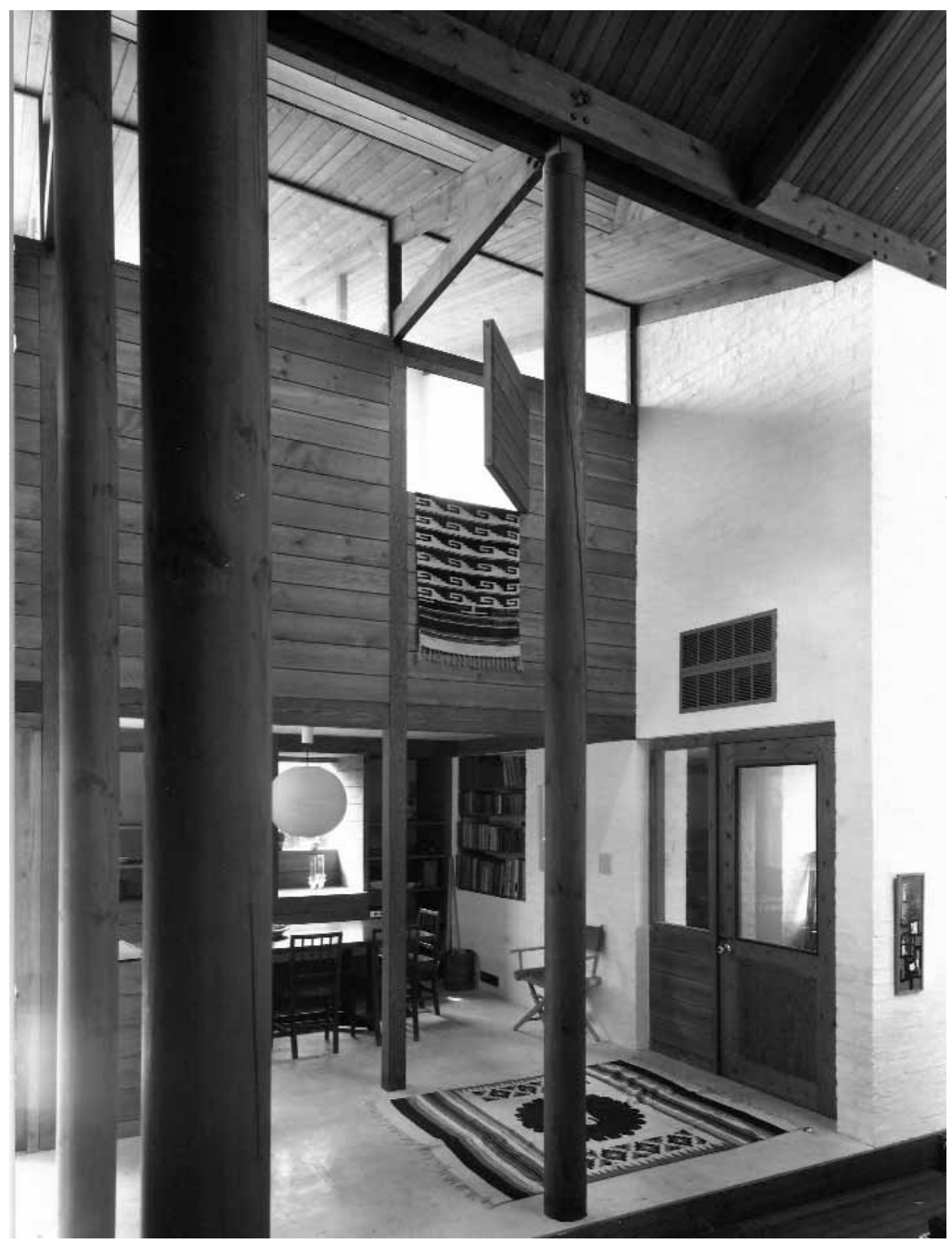

5 Interior of Cornford House living hall looking towards dining space, 1967. Photo A. F. Kersting 
'inhumane' at the heart of the Modernism that had once enraptured him. He had run a tireless mission to examine, articulate and then expose this, often with almost messianic intensity since 1957 . Importantly this theoretical position was stimulated by the traditions in which form is derived from content in the work of Aalto and his contemporaries, Häring, and Scharoun, and back to its forebears in the English Free-School, but also by his study of 'use' in Aristotle and Wittgenstein. He explored these ideas in 'Open and Closed' in the Yale journal Perspecta in 1961, and further enunciated them again in developed form, to stunning effect, in his paper 'Alvar Aalto and the State of Modernism', given at the First International Alvar Aalto Symposium in 1979: thereafter developed his long and close relationship with the Finnish architecture scene.

\section{The urn and the chamberpot}

Thus, for Wilson there was now an ethical imperative at the heart of his architectural world - namely that the architect should study the complex and intricate practical needs inherent in the 'problem', in order to create an appropriate brief from which a building form would grow. In his exploration he often cited Wittgenstein - 'don't ask for the meaning; ask for the use', and increasingly demonstrated a consequent disapproval of architecture predicated on either architectural fashion or the architect's ego - which is not to say that Wilson did not have a strong ego, but it did not impinge on the nature of the architecture his practice designed. Indeed, Wilson's buildings are imbued with humility in the practice of a principle towards enriching and well functioning buildings, as he and his colleagues painstakingly grappled with, and most importantly mastered the immense complexity of briefs; not least in the example of the British Library, but also for other immensely successful later projects, such as the British Museum Extension (1979), or the Queen Mary Library (1989).

By the mid 196os, in addition to the intimacy of the Cornford House, Wilson's small practice was punching above its weight, taking on the immense urban conundrum of the Liverpool Civic and Social Centre project, for which it was selected against international opposition from practices such as SOM. This was mega-architecture which, again, grew from careful studies of the cityscape, a lengthy and complicated methodical analysis to form the brief, and the formal resurrection of the ancient idea of an atrium - long before this became the vogue in the many bland office developments of the 1980s. Eight years, and two innovative schemes later, and after epic negotiations and political manoeuvring, the incoming Liberal regime in the city pulled the plug on the project - a disappointment that was to be repeated when the innovative aedicular grid formation of the Lucas Headquarters project (1975) remained unrealised ten years later.

\section{The British Library}

In 1962 Martin and Wilson had been commissioned to design a new building for the British Museum Library on the site opposite the Museum's Great Russell Street front. Some years later, in the course of a major reorganisation which led to the evolution of the British Library, the project was revived in enlarged form. Martin stepped aside at this point and Wilson took over responsibility for the enlarged project. After a series of feasibility studies - including a development plan for the British Museum design commenced on the same site for a new humanities and science library, limited commercial accommodation and extensive housing for Camden. The entire west side of Bloomsbury Square was retained and Hawksmoor's great church acted as a focal point in the design. Completed in 1972, the project fell foul of the conservationists and the oil crisis. In 1975, a new site, at St. Pancras, was proposed and, after a feasibility study, approved. A completely new building form emerged but what remained constant was the immense expertise, particularly of M. J. Long and Peter Carolin, gained from the years of brief-building with the Library Planning Group, on which the excellent functioning of the new British Library was predicated.

In 1975, Wilson was also made Professor of Architecture at Cambridge, and thus began a

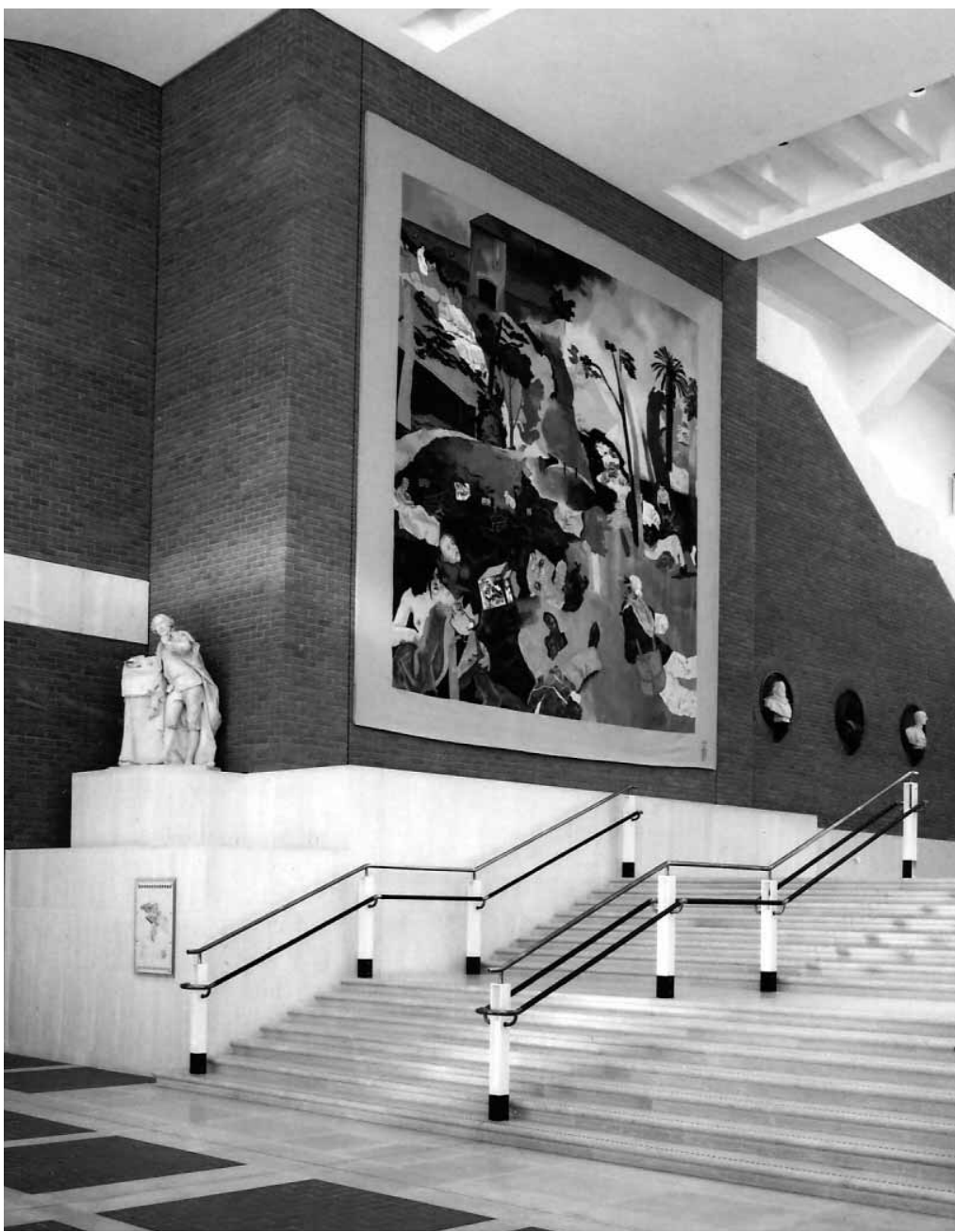

6 British Library Foyer Steps with Tapestry based on R. B. Kitaj's If Not, Not and Roubiliac's figure of Shakespeare, 1998 
peripatetic existence, stimulating the teaching and research at Cambridge, while also overseeing the British Library project in London with his partners, among whom was M. J. Long, whom he married the same year. Wilson drew to the Cambridge School a catholicity of academic thought that stimulated a great dialogue of ideas. At this time he also progressed both his theoretical writing, much of which was later re-published in his collection of essays, Architectural Reflections (1992), and building towards his treatise The Other Tradition of Modern Architecture (1995). ${ }^{10}$ He was frequently invited to teach and lecture around the world, and as well as four periods as Visiting Professor at Yale, he was Visiting Professor at MIT on two occasions.

This is not the place to resurrect the controversy surrounding the British Library [6], but to celebrate the fact of its extraordinary achievement - be it the fact of a well functioning library; the richness of both the expansive and the intimate spaces; the welcome tranquillity of the piazza; the magnificence of the foyer which is both intimate and at the same time vast; the gem of the King's Library; the Italianate drama of the restaurant; the richness of the railings; the intimacy of the marble seats; the solid finery of the door handles; and not to mention the integration therein of pieces of art specially commissioned, such as Kitaj's vast 'If not, not'. At all scales from the most intimate detail to the monumental public spaces, the library speaks volumes - but mostly about the value of those using it, for whom Wilson laboured on and off from 1962 to 1998. In his last year Wilson worked with Long and Kentish, the practice his wife and a colleague established during the last years of the British Library project, on the completion of the Extension to the British Library to house the Conservation Centre. It was with great irony that, in the year that the British Library opened, Wilson was knighted by Prince Charles for his services to architecture.

\section{Pallant House Gallery}

Fittingly, Wilson's passion for collecting art led to an enjoyable conundrum in his later years what to do with the exceptional collection of British art he had accumulated. Wilson and Long decided to donate it to the Pallant House Gallery in Chichester, and in July 2006 the Pallant House Gallery Extension [7] designed by Wilson

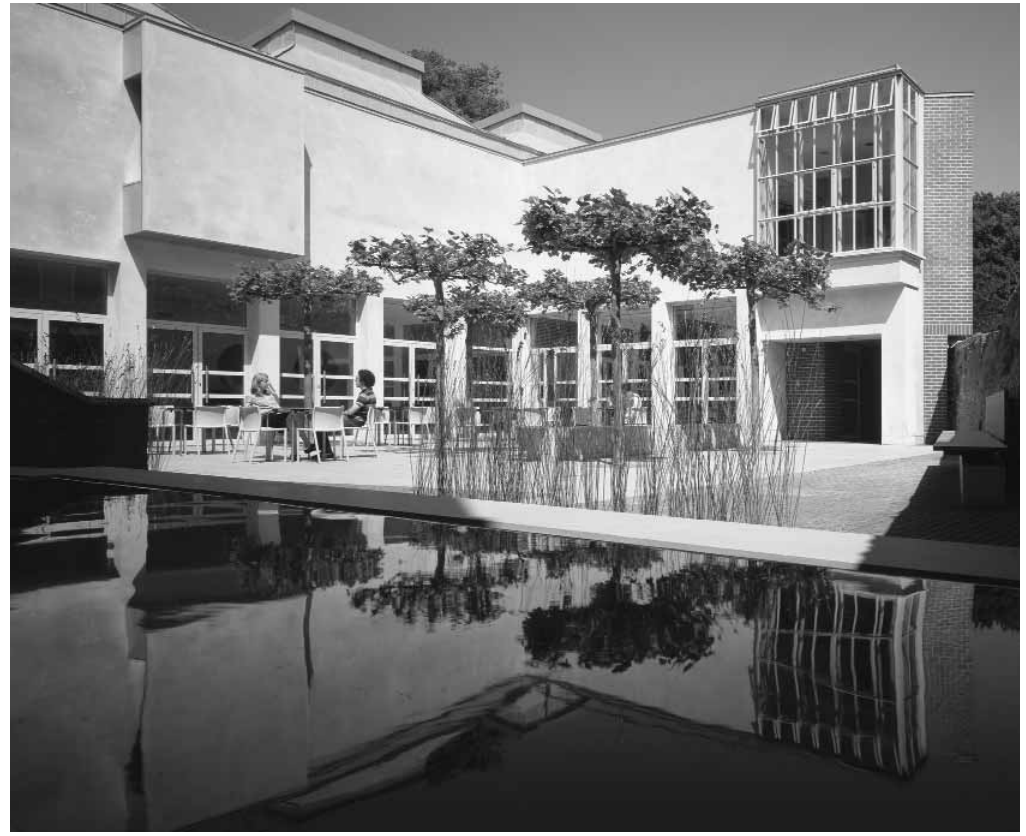

7 Courtyard of Pallant House Gallery Extension, 2006

with Long and Kentish, opened. A few days after Wilson's death the gallery was awarded the prestigious Gulbenkian Prize for Museums and Galleries for 2007. Such recognition of Wilson's work is long overdue, and the richness of this gallery remains a fitting legacy to his passion for art, his generosity of spirit and his skill as one who could envisage architectural spaces fit for purpose in practical terms, and most importantly in terms of the psycho-physical human experience. ${ }^{1}$

Indeed, it is a mark of his success that children, who do not recognise the academic agendas, naturally delight in his work as they relate instinctively to the spaces and the materials - and in none more so than the British Library. The making of such inviting spaces was part of an ethical imperative about which he preached, and that he believed was at the heart of architecture.

\section{SARAH MENIN}

Sarah Menin is a Visiting Fellow at the School of Architecture Planning and Landscape at Newcastle upon Tyne, and author of, among other things, An Architecture of Invitation: Colin St. John Wilson (Ashgate, 2005) with Stephen Kite, Constructing Place (Routledge, 2002) and Nature and Space: Aalto and Le Corbusier (Routledge, 2003) with Flora Samuel.

\section{Notes}

1. For a critical analysis of Wilson's work see Sarah Menin \& Stephen Kite, An Architecture of Invitation: Colin St. John Wilson (London: Ashgate, 2005).
2. Alvar Aalto, 'Instead of an Article' (1958), in Sketches, ed. by G. Schildt (Cambridge, MA: MIT, 1985), p. 161

3. Colin St. John Wilson, National Sound Archive, Tape 1a.

4. Colin St. John Wilson, 'The Ethics of Architecture', in Architectural Reflections (Oxford: Butterworth, 1992), pp. 20-52.

5. Stephen Kite \& Sarah Menin, 'Towards a New Cathedral: Mechanolatry and Metaphysics in the Milieu of Colin St. John Wilson', Architectural Research Quarterly, vol. 9, no. 1 (2005), 81-90.

6. This was a collaboration between Wilson, Carter, the engineer Frank Newby and the sculptor Robert Adams.

7. Martin Richardson, 'Colin St. John Wilson', in Colin St. John Wilson (London: RIBA, 1997), p. 18.

8. Stephen Kite \& Sarah Menin, 'Philosophy and Psychology of the aedicule - John Summerson and Colin St. John Wilson', Ptah (Alvar Aalto Foundation Journal, Helsinki), no. 1 (2005), 11-23.

9. Sarah Menin, 'Accessing the Essence of Architecture: "In-between" Nature and Modernity in Aalto's Engineers Housing in Sunila', Thresholds, no. 32, 'Access' (2006), 47-52.

10.Colin St. John Wilson, The Other Tradition of Modern Architecture (London: Academy Editions, 1995).

11. Menin \& Kite, An Architecture of Invitation: Colin St. John Wilson (London: Ashgate, 2005).

\section{Illustration credits}

arq gratefully acknowledges:

Author, 1

Wilson Archive, 2, 3, 4, 5

John Donat, 6

Peter Durant/arcblue.com, 7 